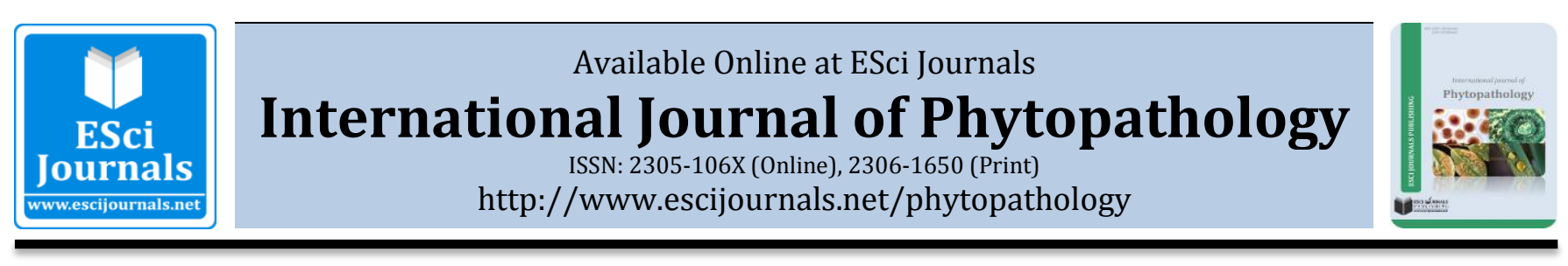

\title{
EFFECT OF VARIABLE PHYSICAL FACTORS ON THE TOXICITY OF PLANT VOLATILES AGAINST SOME ASPERGILLUS SPP.
}

\author{
aAbhay K. Pandey, aPooja Singh*, bUma T. Palni, aNijendra N. Tripathi \\ a Department of Botany, DDU Gorakhpur University, Gorakhpur-273009, India. \\ b Department of Botany, DSB Campus, Kumaun University, Nainital-263002, India.
}

\section{A B S T RA C T}

The objective of the present study is to investigate the effect of physical factors on mycotoxic potency of Chenopodium ambrosioides Linn. and Clausena pentaphylla (Roxb.) DC oils against four species of Aspergilli such as A. flavus Link, $A$. niger van Tieghem, A. ochraceus Wilhelm, A. terreus Thom causing post-harvest deterioration of pigeon pea seeds. During experimentation it was observed that the potency of both oils remained unchanged even against heavy inoculum dose (maximum number of 10 fungal discs and diameter of $25 \mathrm{~mm}$ ). Furthermore, the toxicity of both the oils did not alter even up to $120^{\circ} \mathrm{C}$ of temperature and 12 months of storage by exhibiting $100 \%$ mycelial inhibition of test fungi. The toxicity of both the oils was decreased at alkaline $\mathrm{pH}(7,8)$. Physicochemical characterization of oils revealed that $C$. ambrosioides oil was pale yellow in colour, lighter than water, laevorotatory, acidic in nature and showed positive test for phenols. While the oil of $C$. pentaphylla had light pale color, dextrorotatory, slightly acidic and showed presence of phenols. Both the oils showed good solubility in various organic solvents.

Keywords: Aspergillus spp., Chenopodium ambrosioides, Cluasena pentaphylla, Essential oils, Physical factors, Physico-chemical properties.

\section{INTRODUCTION}

Essential oils keep stored food commodities free from pathogenic microorganisms, because they entail special promise for use as fumigants. These being lipophilic, can easily penetrate deeper through living tissue unbarred by selective permeability of cell membrane; hence they are of interest in the management of deep seated seed borne fungi (Lalitha and Raveesha, 2006). The essential oil of Chenopodium ambrosioides had earlier been reported to possess strong antifungal activity (Kumar et al., 2007) but mycotoxic reports on Clausena pentaphylla has not been studied. In previous studies we have screened essential oils against four dominant species of Aspergillius of stored pigeon pea seeds during which Chenopodium and Clausena oils were reported to be caused absolute toxicity, inhibiting mycelial growth of all test fungi at their MICs of $0.07 \mu \mathrm{l} / \mathrm{ml}$. The present study was undertaken to investigate the changes in potency of Chenopodium and Clausena oils (at their MICs) under the

\footnotetext{
* Corresponding Author:

Email: pooja.ddu@gmail.com

(C) 2014 ESci Journals Publishing. All rights reserved.
}

influence of different physical factors. Further physicochemical properties of both the oils were also assessed for their standardization.

\section{MATERIALS AND METHODS}

Freshly collected twigs and leaves of plant species viz., Chenopodium ambrosioides and Clausena pentaphylla respectively were subjected to hydrodistilation in Clevenger type apparatus for isolation of essential oils separately. The essential oils were dried over anhydrous sodium sulphate and were stored at $4 \pm 1{ }^{\circ} \mathrm{C}$ in dark places. The effect of different physical parameters viz., inoculum density, storage, temperature and autoclaving on fungal toxicity of the oils was studied by Inverted Petri plate method following Bocher (1938) at MIC of $0.07 \mu \mathrm{l} / \mathrm{ml}$. The test fungi were Aspergillus flavus, A. niger, A. ochraceus and A. terreus. A control set was maintained without essential oils. All the experiments were carried out in triplicates. The results were recorded in terms of per cent mycelial inhibition.

The effect of $\mathrm{pH}$ on potency of oils was done by Inverted Petri plate (Bocher, 1938) as well as poison food method (Grover and Moore, 1962). The pH of oils was 
determined by Elico pH meter. During Inverted Petri plate method, $\mathrm{pH}$ of oil was changed following the method of Shahi et al. (1999) with slight modification. Requisite amount of oil was mixed in PEG (Polyethylene glycol) and $\mathrm{pH}$ was adjusted at 5, 7 and 8 (using $1 \mathrm{~N}$ $\mathrm{NaOH}$ and $\mathrm{HCl}$ ) for Chenopodium (original $\mathrm{pH} 6$ ) and 6, 7 and 8 for Clausena oil (original pH 5). However, during poison food method $\mathrm{pH}$ of medium was amended using citrate phosphate buffer following Dixit et al. (1982). The results were recorded in terms of per cent mycelial inhibition. Assays were maintained in triplicates. During each experiment a control set was maintained without additive.

Both the oils were standardized by determining their various physico-chemical properties viz. specific gravity, specific rotation, refractive index, acid number, saponification number, ester number, test for presence of phenolic content and solubility in various organic solvents following Langenau (1948).

\section{RESULTS AND DISCUSSION}

During experiments it was observed that both oils inhibited the growth of all ten discs as well as the growth of single mycelial disc of $25 \mathrm{~mm}$ diam of test fungi except Aspergillus terreus (Table 1). Both the oils remained effective after one year of storage exhibiting long shelf life (Table 2). The oil retained their fungitoxicity after exposure up to $120^{\circ} \mathrm{C}$ indicating their thermostable nature (Table 3). Autoclaving $\left(15 \mathrm{lb} / \mathrm{inch}^{2}\right.$ pressure for $15 \mathrm{~min}$.) had no adverse effect on the toxicity of the oils against the test fungi. According to Wellman (1967), a pesticide must be stable to extreme of temperature and long shelf life. However the effects of storage and temperature on pesticidal activity of the oils have received little attention. Shukla (2009) reported that oil of Cymbopogon pendulus was thermostable up to $80^{\circ} \mathrm{C}$ and toxic for 36 months. Similarly, in present investigation the toxicity of both oils was thermostable upto $120^{\circ} \mathrm{C}$ and persisted for 12 months of storage.

The original pH of $C$. ambrosioides and C. pentaphylla oil was 6 and 5 respectively. Both the oils exhibited maximum toxicity against all the test fungi at $\mathrm{pH} \mathrm{5,6}$ and 7 when assessed by Inverted Petri plate method (Table 4). However during poisoned food method both the oils at the $\mathrm{pH}$ of 5 and 6 exhibited maximum toxicity towards A. flavus, A. niger and A. ochraceus while only $\mathrm{pH} 6$ exhibited absolute toxicity for $A$. terreus (Table 5). The $\mathrm{pH}$ of the media has long been known to be a major influence on the growth of bacteria and fungi with most microorganisms having optimum growth in the range of pH 6-8 (Hood et al., 2004). In previous studies pH was found to have profound influence on the fungitoxicity of the oils (Pandey et al., 1982). Dixit et al. (1981) demonstrated that after amending the $\mathrm{pH}$ of test media, the fungitoxicity of Cedrus oil increased 6 times at $\mathrm{pH} 9$ while that of Mentha oil 4 times at $\mathrm{pH}$ 9. Shahi et al. (1999) reported that efficacy of several Eucalyptus spp. oils against six dermatophytes increases when $\mathrm{pH}$ of test media is either increased or decreased. In both studies author adjusted the $\mathrm{pH}$ of the media prior to addition of essential oil and hence it is unknown what affect the essential oil had on media $\mathrm{pH}$. In our study $\mathrm{pH}$ of media as well as oils was changed. The present work shows that toxicity of both the oils decreased at alkaline $\mathrm{pH}$. Thus during fungitoxic preparations related to oils the activity of the oil can be enhanced by addition of acidic adjuvants.

Table 1. Effect of increased fungal inoculum on toxicity of essential oils.

\begin{tabular}{|c|c|c|c|c|c|c|c|c|}
\hline \multirow{3}{*}{ No./Diam. of inoculated disc } & \multicolumn{8}{|c|}{ Appearance of growth present $(+) /$ absent $(-)^{*}$} \\
\hline & \multicolumn{4}{|c|}{ Chenopodium ambrosioides } & \multicolumn{4}{|c|}{ Clausena pentaphylla } \\
\hline & $A F$ & $A N$ & $A O$ & $A T$ & $A F$ & $A N$ & $A O$ & $A T$ \\
\hline \multicolumn{9}{|l|}{ (a) No. of inoculum disc of $5 \mathrm{~mm}$. } \\
\hline 2 & - & - & - & + & - & - & - & + \\
\hline 4 & - & - & - & + & - & - & - & + \\
\hline 6 & - & - & - & + & - & - & - & + \\
\hline 8 & - & - & - & + & - & - & - & + \\
\hline 10 & - & - & - & + & - & - & - & + \\
\hline \multicolumn{9}{|l|}{ (b) Diameter of inoculum disc in mm. } \\
\hline 10 & - & - & - & + & - & - & - & + \\
\hline 15 & - & - & - & + & - & - & - & + \\
\hline 20 & - & - & - & + & - & - & - & + \\
\hline 25 & - & - & - & + & - & - & - & + \\
\hline
\end{tabular}

AF-Aspergillus flavus, AN- A. niger, AO- A. ochraceus, AT- A. terreus, * Oil concentration $0.07 \mu \mathrm{l} / \mathrm{ml}$. 
Table 2. Fungal toxicity of oils stored for different periods.

\begin{tabular}{ccccccccc}
\hline \multirow{2}{*}{$\begin{array}{c}\text { Storage period } \\
\text { (in months) }\end{array}$} & \multicolumn{9}{c}{ Chenopodium ambrosioides } \\
\cline { 2 - 9 } & $A F$ & $A N$ & $A O$ & $A T$ & $A F$ & $A N$ & $A O$ & $A T$ \\
\hline 3 & 100 & 100 & 100 & 100 & 100 & 100 & 100 & 100 \\
6 & 100 & 100 & 100 & 100 & 100 & 100 & 100 & 100 \\
9 & 100 & 100 & 100 & 100 & 100 & 100 & 100 & 100 \\
12 & 100 & 100 & 100 & 100 & 100 & 100 & 100 & 100 \\
\hline
\end{tabular}

\$ Duration of storage- November 2008- October 2009

Table 3. Fungal toxicity of oils treated to different temperatures.

\begin{tabular}{ccccccccc}
\hline \multirow{2}{*}{$\begin{array}{c}\text { Temperature } \\
\left(\text { in }{ }^{\circ} \mathrm{C}\right)\end{array}$} & \multicolumn{7}{c}{ Chenopodium ambrosioides } & \multicolumn{5}{c}{ Clausena pentaphylla } \\
\cline { 2 - 8 } & $A F$ & $A N$ & $A O$ & $A T$ & $A F$ & $A N$ & $A O$ & $A T$ \\
\hline 40 & 100 & 100 & 100 & 100 & 100 & 100 & 100 & 100 \\
60 & 100 & 100 & 100 & 100 & 100 & 100 & 100 & 100 \\
80 & 100 & 100 & 100 & 100 & 100 & 100 & 100 & 100 \\
100 & 100 & 100 & 100 & 100 & 100 & 100 & 100 & 100 \\
120 & 100 & 100 & 100 & 100 & 100 & 100 & 100 & 100 \\
\hline
\end{tabular}

Table 4. Effect of pH on toxicity of oils by Inverted Petri plate method.

\begin{tabular}{|c|c|c|c|c|c|c|c|c|}
\hline \multirow{3}{*}{ pH levels } & \multicolumn{8}{|c|}{ Per cent mycelial inhibition* } \\
\hline & \multicolumn{4}{|c|}{ Chenopodium ambrosioides } & \multicolumn{4}{|c|}{ Clausena pentaphylla } \\
\hline & $A F$ & $A N$ & $A O$ & $A T$ & $A F$ & $A N$ & $A O$ & $A T$ \\
\hline 5 & 100 & 100 & 100 & 100 & 100 & 100 & 100 & 100 \\
\hline 6 & 100 & 100 & 100 & 100 & 100 & 100 & 100 & 100 \\
\hline 7 & 93.27 & 100 & 96.22 & 100 & 100 & 91.48 & 89.80 & 100 \\
\hline 8 & 97.10 & 100 & 95.76 & 100 & 100 & 100 & 100 & 88.23 \\
\hline
\end{tabular}

Table 5. Effect of pH on toxicity of oils by poison food method.

\begin{tabular}{ccccccccc}
\hline & \multicolumn{7}{c}{ Per cent mycelial inhibition* } \\
\cline { 2 - 9 } pH levels & \multicolumn{7}{c}{ Chenopodium ambrosioides } & \multicolumn{5}{c}{ Clausena pentaphylla } \\
\cline { 2 - 9 } & $A F$ & $A N$ & $A O$ & $A T$ & $A F$ & $A N$ & $A O$ & $A T$ \\
\hline 5 & 100 & 100 & 100 & 97.86 & 100 & 100 & 100 & 98.8 \\
6 & 100 & 100 & 100 & 100 & 100 & 100 & 100 & 100 \\
7 & 93.27 & 90.40 & 96.22 & 94.98 & 93.34 & 91.48 & 89.80 & 92.50 \\
8 & 97.10 & 79.54 & 95.76 & 90.67 & 83.45 & 80.67 & 82.54 & 78.03 \\
\hline
\end{tabular}

Essential oils are mixture of organic substances of heterogeneous groups, the level of which may vary with plants growing in different ecological situations. Hence the quality of biologically active essential oils must be standardized in order to get the reproducible results (Rehman et al., 2007).

In present study therefore quality of fungitoxic oils was standardized by their various physicochemical properties. Table 6 reveals the physico-chemical characterization of Chenopodium and Clausena oils as an ideal fungitoxicants. Oil of C. ambrosioides was pale yellow in colour, lighter than water (specific gravity 0.8199 at $25^{\circ} \mathrm{C}$ ), laevorotatory (specific rotation $-6^{\circ} 2^{\prime}$ at $25^{\circ} \mathrm{C}$ ), acidic in nature and showed positive test for phenols. Oil was immiscible in water, while exhibited good solubility in various organic solvents. 
Table 6. Physico-chemical properties of essential oils.

\begin{tabular}{lll}
\hline \multirow{2}{*}{ Parameters } & \multicolumn{2}{c}{ Values } \\
\cline { 2 - 3 } \multicolumn{1}{c}{ Colour } & \multicolumn{1}{c}{ Cellow } & \multicolumn{1}{c}{ Clausena pentaphylla } \\
Specific gravity & 0.8199 at $25^{\circ} \mathrm{C}$ & 1.2415 at $25^{\circ} \mathrm{C}$ \\
Specific rotation & $-6^{\circ} 2^{\prime}$ at $25^{\circ} \mathrm{C}$ & $+0.12^{\circ} 28^{\prime}$ at $22^{\circ} \mathrm{C}$ \\
Refractive index & 1.436 at $29^{\circ} \mathrm{C}$ & 1.529 at $26^{\circ} \mathrm{C}$ \\
Acid value & 16.35 & 2.992 \\
Saponification number & 164.55 & 52.36 \\
Ester number & 181.30 & 49.37 \\
Phenolic content & Present & Present \\
Solubility & $1: 1$ Soluble in $90 \%$ alcohol, $1: 2$ in Acetone and & $1: 1$ Soluble in $90 \%$ alcohol, in \\
& Ethyl acetate but insoluble in water & Acetone and Ethyl acetate but \\
& & insoluble in water \\
\hline
\end{tabular}

The oil of $C$. pentaphylla had specific gravity 1.2415 , oil was dextrorotatory $\left(+0.12^{\circ} 28^{\prime}\right.$ at $\left.22^{\circ} \mathrm{C}\right)$, slightly acidic, showed presence of phenols and good solubility in various organic solvents but insoluble in water.

In conclusion the findings suggest that Chenopodium and Clausena oils can be exploited as an ideal fungitoxicant against storage fungi due to their long shelf life, persistent toxicity at high temperature, activity at heavy inoculum doses and at variable ranges of $\mathrm{pH}$.

\section{ACKNOWLEDGEMENTS}

Authors are thank to CST UP, Lucknow for financial support, Head Department of Botany, DDU Gorakhpur University for providing necessary Lab. Facilities, and Staff, BSI (NRC) Dehradun to validate the authentication of plant specimens.

\section{REFERENCES}

Bocher, O.E. 1938. Antibiotics: In Modern Methods of Plant analysis eds. Peach K \& Tracey MV vol III Springer verlog, Berlin. Pp 651.

Dixit, A., A.K. Singh and A.K. Dixit. 1981. Effect of $\mathrm{pH}$ on fungitoxic activity of some essential oils. Journal of Antibacterial Antifungal Agents. 9: 9-10.

Grover, R.K. and J.D. Moore. 1962. Toximetric studies of fungicides against brown rot organism Sclerotinia fructicola and S. laxa. Phytopathology. 52: 876880.

Hood, J.R., H.M.A. Cavanaghand and J.M. Wilkinson. 2004. Effect of essential oil concentration on the $\mathrm{pH}$ of nutrient and iso-sensitest broth. Phytotherapy Research. 18: 947-949.

Kumar, R., A.K. Mishra, N.K. Dubey and Y.B. Tripathi. 2007. Evaluation of Chenopodium ambrosioides oil as a potential source of antifungal, antiaflatoxigenic and antioxidant activity. International Journal of Food Microbiology. 115: 159-164.

Lalitha, V. and K.A. Raveesha. 2006. Fungitoxicity of some essential oils against important seed borne pathogens of paddy. Plant Disease Research. 21: 155-157.

Langenau, E.E. 1948. The examination and analysis of essential oils, synthetics and isolates. In: The essential oils. Vol.1. Guenther, E. (ed.). Roberts E. Krieger Publishing Co. Huntington, New York. Pp. 227-348.

Pandey, D.K., N.N. Tripathi, R.D. Tripathi and S.N. Dixit. 1982. Fungitoxic and phytotoxic properties of the essential oil of Hyptis suaveolens. Journal of Plant Disease and Protection. 89: 344-349.

Rehman, S.U., M.M. Ahmad, Z.H. Kazmiand M.S. Raza. 2007. Physico-chemical variations in essential oils of Citrus reticulata. Journal of Food Science and Technology. 44: 353-356.

Shahi, S.K., A.C. Shukla, and A. Dixit. 1999. Antifungal studies of some essential oils at various $\mathrm{pH}$ levels for betterment of antifungal drug response. Current Science. 77: 703-706.

Shukla, A.C. 2009. Volatile oil of Cymbopogon pendulus as an effective fumigant pesticide for the management of storage-pests of food commodities. National Academy Science Letter. 32: 51-59.

Wellman, R.H. 1967. Commercial development of fungicides. Hollen et al. (ed.) Plant Pathology Problems and Progress. Indian University Press Allahabad, (1908-1958). 